\section{Environmentalists warn of continued threats to water supplies}

DESPITE progress in reducing the more obvious sources of water pollution, US regulators are beginning to feel that problems in maintaining a clean and healthy water supply will play as controversial a role on the political agenda of the 1980s as the energy crises has done during the 1970s.

The latest warning of difficulties still to be faced comes from the Council on Environmental Quality, the watchdog committee established by President Nixon in 1970. In its latest annual report, published in Washington last week, the council says that the general standard of air quality has increased substantially over the past decade. In contrast progress in cleaning up water supplies has been far less impressive.

In particular, the council says that ground-water contamination from various activities, such as the use of pesticides in agriculture or the improper disposal of toxic wastes, is becoming a major problem for drinking-water supplies in parts of the country.

It draws attention to the impact of "acid rain" on wildlife and water quality: and looking ahead, picks out the problems of carcinogens in drinking water, supplies to "water-starved areas", and ageing distribution systems as three "basic and difficult problems" that the nation will have to face in the next few years.

Coming to grips with such problems may require new legislation and substantial resources: updating distribution systems, for example, could cost $\$ 50$ billion to $\$ 100$ billion nationwide to prevent large-scale disruption of supplies.

Yet left unsaid by the CEQ is that the Environmental Protection Agency is already struggling to carry out existing responsibilities which it has been given by Congress and in many cases the agency is meeting strong opposition from water utilities, who claim that new regulations to control toxic substances in water, for example, are over-restrictive and unnecessarily expensive.

Not that the picture is all gloom. The CEQ's report points out that there has been considerable success in controlling efficient emissions from factories and other identifiable industrial activities since the Clean Water Act was passed by Congress in 1973.

But statistics illustrate the severity of the problems that remain. Thus the report says that as many as two-thirds of the nation's lakes may have serious pollution problems and that an estimated $80 \%$ of the 37,700 lakes in urban areas in the US are "significantly degraded".

This pollution is inevitably taking its toll of wild-life. In many lakes and rivers, toxic chemical contaminants such as PCBs have made fish inedible. Acid rain has made many lakes, particularly in the northeastern United States, lethal to fish and other aquatic life and four million acres of commercial shell-fish waters have been closed.

The extent of the continuing pollution problem is also demonstrated by the fact that there has been "little or no overall change in the levels of five major water pollution indicators - fecal coliform bacteria, dissolved oxygen, total phosphorus content, total mercury, and total lead - over the four years 1975 to 1978, the CEQ reports.

Industry, in some ways a comparatively easy target for the EPA, has responded relatively well to control legislation. Although some industries, in particular the steel industry, have resisted stringent effluent restrictions, $90 \%$ of industrial discharges now meet "best practicable technology" standards laid down in 1977.

Municipalities responsible for water treatment have been more of a problem. Although federal funds have been made available for sewage treatment facilities since 1973 , for example, many urban areas have been reluctant to take them up. Elsewhere construction projects have been plagued by cost-overruns and profiteering.

As a result, municipal sewage wastes are still "years away from being totally controlled" says the CEQ.

Furthermore both industry and water utilities are responding warily to what one EPA official refers to as the "second generation of water clean-up" shifting attention from more well-known and obvious pollutants to the long term effects
THE US Consumer Product Safety Commission announced last week that it is to set up a panel to help assess the human implications of research findings that exposure to formaldehyde can cause cancer in laboratory rats. The panel will be Toxicology Programme, and will be assembled from various federal health and organisations.

Last October, scientists from the Chemical Industry Institute of Toxicology and the Formaldehyde Institute reported established in conjuction with the National safety agencies and scientific of relatively low levels of toxic substances.

The agency, for example, is already experiencing considerable difficulty in carrying out some of the requirements of the Safe Drinking Water Act of 1974, introduced after environmentalists found abnormally high cancer rates among residents of Louisiana who used water supplies from the Mississippi river.

Further difficulties are likely to face the EPA as it moves to implement industry-byindustry guidelines for the regulation of 129 top priority pollutants - mainly heavy metals and substances known or suspected to be carcinogenic - agreed after pressure from groups such as the Environmental Defense Fund to follow through on the agency's congressional mandate.

Then there is the growing problem of acid rain. This is caused when emission from automobiles or power-plants combines with water in the atmosphere.

Here the CEQ points out that in the eastern half of the US the acidity of rainfall appears to have increased about 50-fold during the past 25 years. In addition to eliminating fish from lakes in the north-eastern US and Canada, acid rain, it says, "is also suspected of contributing to the leaching of toxic compounds into drinking water, especially surface water supplies"'.

All these problems are likely to mean increased responsibilities for the EPA. And the CEQ indicates that it is well aware of the difficulties faced, for example, in shifting the focus of control from point to "non-point" sources of pollution, such as run-off from construction sites, agricultural land or chemical dumps.

On top of all the other problems, the EPA is now faced with a bill introduced into the House of Representatives by Representative Phill Gramm of Texas, which would seriously limit its ability to enforce new quality controls: few believe the bill would pass solely on its technical merits but it could ride on the back of popular anti-regulatory sentiment and win a surprise victory.

David Dickson

\title{
Panel to assess formaldehyde health effects
}

that three laboratory rats of several hundred exposed to formaldehyde gas had developed prominent nasal cancers which were identified as squamos cell carcinoma.

Health scientists from CPSC and other regulatory agencies were told last month that such cancers were now evident in 37 of the rats in the study, which is three-quarters of the way through its two-year duration. In a random sample of rats selected for sacrifice and pathological examination after exposure at the dose level of 15 parts per million, $20 \%$ showed evidence of squamous cell carcinoma. 